\title{
Advantage Analysis of Composite Girder with Corrugated Steel Web Compared with Concrete Girder in Continuous Rigid Frame Bridge
}

\author{
Guangling LI, Yanchi WU*, Zhiyong ZHAO \\ School of Highway \\ Chang`an University \\ Xian, China \\ e-mail:372286253@qq.com,2267058312@qq.com,1035407715@qq.com
}

\begin{abstract}
This paper focuses on the application, characteristics and advantages of composite girder with corrugated steel webs at home and aboard. The comparison between concrete girder and composite girder includes material quantity, intensity and stiffness. The results show that composite beam has saving on the material quantity and the use of composite beam would avoid burdensome procedure and speed the construction period. Composite beam would also have a larger bearing capacity and a smaller stiffness.
\end{abstract}

Keywords-composite girder; corrugated steel web; rigid frame bridge

\section{INTRODUCTION}

With the increasing span of the prestressed concrete bridge, the dead-weight of bridge has become a constraint to its span capacity. The French put forward a new type of steel-concrete composite box-girder to solve this problem, and they decided to replace the traditional concrete web with corrugated steel web. Cognac Bridge is the first steelconcrete composite box-girder bridge.

Since then, many other countries have built the same type bridges and made the steel-concrete composite box-girder available all the world, especially in Japan [1]. Japanese bridge engineers have done a lot of research on this type and built more than 200 similar bridges. Also, the corrugated steel web bridge norms in design and construction are sophisticated and standardized and including beam bridge, arch bridge, cable-stayed bridge and so on.

In recent years, composite box-girder bridges with the corrugated steel webs have developed rapidly in China, Table 1 shows some examples.

\section{CHARACTERISTICS OF COMPOSITE BOX-GIRDER BRIDGES WITH THE CORRUGATED STEEL WEBS}

Composite box-girder bridges with the corrugated steel webs consist of top-and-bottom concrete board, pre-stressed tendons and corrugated steel webs. Figure 1 shows the normal form of this type.

Compared with the concrete girder bridges, composite girder bridges with the corrugated steel webs has the following advantages:(a) the dead-weight of girder is reduced by $20 \% \sim 30 \%$ because of the use of corrugated steel webs; (b) the efficiency of pre-stressing is improved and the influence of temperature and concrete shrinkage and creep on the top-and-bottom board is reduced; (c) the shear strength of corrugated steel web is relatively high; (d) the adoption of external pre-stressed tendons could avoid the difficulties of the construction and is beneficial to the maintenance of the bridge; (e) corrugated steel webs have a high degree of standardization and could be made in the factories, which means the quick speed of construction.

TABLE I. SOME CHINESE COMPOSITE BOX-GIRDER BRIDGES WITH THE CORRUGATED STEEL WEBS

\begin{tabular}{|c|c|c|c|}
\hline Bridge Name & Construction Type & $\operatorname{Span}[\mathrm{m}]$ & Girder Type \\
\hline Henan Guangpo & $\begin{array}{c}\text { Continuous girder } \\
\text { bridge }\end{array}$ & $4 \times 30$ & Small box girder \\
\hline $\begin{array}{l}\text { Jiangsu Huaian } \\
\text { Changzheng }\end{array}$ & $\begin{array}{c}\text { Continuous girder } \\
\text { bridge }\end{array}$ & $18.5+30+18.5$ & - \\
\hline $\begin{array}{c}\text { Chongqing } \\
\text { Yongchuan Dayan } \\
\text { River }\end{array}$ & $\begin{array}{l}\text { Simply supported } \\
\text { girder bridge }\end{array}$ & 23.7 & $\begin{array}{l}\text { Single box } \\
\text { single-cell }\end{array}$ \\
\hline $\begin{array}{c}\text { Qinghai Sandao } \\
\text { River }\end{array}$ & $\begin{array}{l}\text { Simply supported } \\
\text { girder bridge }\end{array}$ & 50 & $\begin{array}{l}\text { Simple-box } \\
\text { double-cell }\end{array}$ \\
\hline $\begin{array}{l}\text { Ningbo Yongxin } \\
\text { River }\end{array}$ & $\begin{array}{l}\text { Continuous girder } \\
\text { bridge }\end{array}$ & $24+40+24$ & $\begin{array}{l}\text { Single box } \\
\text { single-cell }\end{array}$ \\
\hline $\begin{array}{c}\text { Shandong Dongying } \\
\text { Yingzuo }\end{array}$ & $\begin{array}{l}\text { Simply supported } \\
\text { girder bridge }\end{array}$ & 38 & $\begin{array}{l}\text { Single box } \\
\text { single-cell }\end{array}$ \\
\hline $\begin{array}{c}\text { Pudong Jiyang Road } \\
\text { Overpass }\end{array}$ & $\begin{array}{c}\text { Continuous girder } \\
\text { bridge }\end{array}$ & $45+45$ & - \\
\hline Miluo Lijia River & $\begin{array}{l}\text { Continuous girder } \\
\text { bridge }\end{array}$ & $20+30+20$ & $\begin{array}{l}\text { Single box } \\
\text { single-cell }\end{array}$ \\
\hline Henan Weihe & $\begin{array}{l}\text { Continuous girder } \\
\text { bridge }\end{array}$ & $47+52+47$ & $\begin{array}{c}\text { Single box triple- } \\
\text { cell }\end{array}$ \\
\hline Juancheng Huanghe & $\begin{array}{l}\text { Continuous rigid } \\
\text { frame bridge }\end{array}$ & $70+11 \times 120+7$ & $\begin{array}{l}\text { Single box } \\
\text { single-cell }\end{array}$ \\
\hline $\begin{array}{c}\text { Nanjing Changjiang } \\
4 \#\end{array}$ & $\begin{array}{l}\text { Continuous girder } \\
\text { bridge }\end{array}$ & $56+96+56$ & $\begin{array}{l}\text { Single box } \\
\text { single-cell }\end{array}$ \\
\hline Yingyugou 2\# & $\begin{array}{c}\text { Continuous girder } \\
\text { bridge }\end{array}$ & $25+65+25$ & $\begin{array}{l}\text { Single box } \\
\text { single-cell }\end{array}$ \\
\hline Xinmi Zhengshui & Cable-stayed bridge & $30+70+30$ & $\begin{array}{l}\text { Discrete simple- } \\
\text { box double-cell }\end{array}$ \\
\hline Shenzheng Nanshan & $\begin{array}{l}\text { Continuous girder } \\
\text { bridge }\end{array}$ & $80+130+80$ & $\begin{array}{l}\text { Simple-box } \\
\text { double-cell }\end{array}$ \\
\hline Shenzheng Pingti & $\begin{array}{c}\text { Continuous girder } \\
\text { bridge }\end{array}$ & $80+130+80$ & $\begin{array}{l}\text { Simple-box } \\
\text { double-cell }\end{array}$ \\
\hline Taohuayu Huanghe & $\begin{array}{c}\text { Continuous girder } \\
\text { bridge }\end{array}$ & $75+135+72$ & $\begin{array}{l}\text { Single box } \\
\text { single-cell }\end{array}$ \\
\hline Xingtai Qili River & $\begin{array}{c}\text { Continuous girder } \\
\text { bridge }\end{array}$ & $88+156+88$ & $\begin{array}{l}\text { Single box } \\
\text { single-cell }\end{array}$ \\
\hline
\end{tabular}




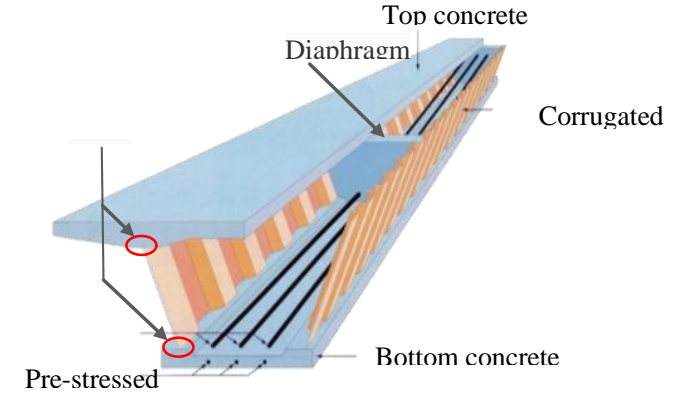

Figure 1. Normal form of composite box-girder bridges with the corrugated steel webs.

\section{COMPARISON OF THE SAME SPAN BetWEEN CONCRETE GIRDER AND COMPOSITE GIRDER WITH THE CORRUGATED STEEL WEBS}

\section{A. General Situation of the Engineering}

1) Continuous rigid frame bridge with concrete girder

The span of continuous rigid frame bridge with concrete girder is $65+2 \times 120+65 \mathrm{~m}$ and the main beam adopts single cell and single box section. The root height of box is $7.2 \mathrm{~m}$, the top board width of box is $15.9 \mathrm{~m}$ and the bottom board width is $8.4 \mathrm{~m}$. The height of the box and the thickness of the bottom board are all changed from the mid-span to the root in the form of 1.8 parabola, which is $3.0 \mathrm{~m}$ high on the midspan and $7.20 \mathrm{~m}$ on the support. The main beam adopts theedirection prestressed system.

2) Continuous rigid frame bridge with composite girder with the corrugated steel webs

The span of continuous rigid frame bridge with composite girder with the corrugated steel webs is $65+5 \times 120+65 \mathrm{~m}$ and the main beam adopts single cell and single box section. The top board width of box is $15.9 \mathrm{~m}$ and the bottom board width is $8.4 \mathrm{~m}$. The height of the box and the thickness of the bottom board are all changed from the mid-span to the root in the form of 1.8 parabola, which is $3.0 \mathrm{~m}$ high on the mid-span and $7.50 \mathrm{~m}$ on the support.

\section{B. Material Quantity Variance}

The quantity of C50 of composite girder with the corrugated steel webs saves $9.2 \%$ per meter compared with concrete girder, and the dead load of girder is reduced; the quantity of steel strand also saves $14.5 \%$ because of the replacement of the concrete web with corrugated steel web and tendons in webs with external pre-stressed tendons; the quantity of vertical fining twisted steel also saves $84.9 \%$. These savings mean that the use of corrugated steel web could effectively avoid burdensome procedure and speed the construction period. Table 2 shows the result of comparison of material quantity.

TABLE II. COMPARISON OF MATERIAL QUANTITY

\begin{tabular}{|c|c|c|c|}
\hline Material qunatity & Concrete girder 1 & Composite girder with the corrugated steel webs(2) & $\begin{array}{c}\text { Saving percent } \\
\text { (1)-(2) } /(1)\end{array}$ \\
\hline $\mathrm{C} 50\left[\mathrm{~kg} / \mathrm{m}^{2}\right]$ & 1.152 & 1.046 & $9.2 \%$ \\
\hline Steel strand $\left[\mathrm{kg} / \mathrm{m}^{2}\right]$ & 73.426 & 62.753 & $14.5 \%$ \\
\hline JL32 fining twisted steel $\left[\mathrm{kg} / \mathrm{m}^{2}\right]$ & 14.042 & 2.115 & $84.9 \%$ \\
\hline $\mathrm{HRB} 400\left[\mathrm{~kg} / \mathrm{m}^{2}\right]$ & 194.041 & 176.212 & $9.2 \%$ \\
\hline Q345D corrugated steel $\mathrm{web}\left[\mathrm{kg} / \mathrm{m}^{2}\right]$ & 1 & 56.722 & I \\
\hline Q345D steel plate $\left[\mathrm{kg} / \mathrm{m}^{2}\right]$ & l & 25.240 & l \\
\hline
\end{tabular}

TABLE III. COMPARISON OF INTENSITY AND STIFFNESS

\begin{tabular}{|c|c|c|c|c|}
\hline & \multicolumn{2}{|l|}{ Items } & Concrete girder & $\begin{array}{l}\text { Composite girder with the } \\
\text { corrugated steel webs }\end{array}$ \\
\hline \multirow{12}{*}{$\begin{array}{l}\text { Dead } \\
\text { Load }\end{array}$} & \multirow{4}{*}{$\begin{array}{l}\text { Midspan } \\
\text { of mid-span }\end{array}$} & Moment [kNom] & 122 & 15133 \\
\hline & & Axial force $[\mathrm{kN}]$ & -75290 & -82221 \\
\hline & & Upper stress[MPa] & -6.0 & -6.6 \\
\hline & & Lower stress[MPa] & -6.6 & -9.4 \\
\hline & \multirow{4}{*}{$\begin{array}{l}\text { Midspan } \\
\text { of side-span }\end{array}$} & Moment $[\mathrm{kN} \bullet \mathrm{m}]$ & 20272 & -42102 \\
\hline & & Axial force $[\mathrm{kN}]$ & -97533 & -89020 \\
\hline & & Upper stress[MPa] & -8.5 & -6.4 \\
\hline & & Lower stress[MPa] & -5.8 & -9.4 \\
\hline & \multirow{4}{*}{$\begin{array}{l}\text { Support } \\
\text { of side-span }\end{array}$} & Moment $[\mathrm{kN} \bullet \mathrm{m}]$ & -140249 & -34497 \\
\hline & & Axial force $[\mathrm{kN}]$ & -220379 & -191193 \\
\hline & & Upper stress[MPa] & -9.7 & -10.7 \\
\hline & & Lower stress[MPa] & -10.8 & -11.4 \\
\hline \multirow{2}{*}{$\begin{array}{l}\text { Live } \\
\text { Load }\end{array}$} & Midspan of mid-span & Deflection $[\mathrm{mm}]$ & -23 & -39 \\
\hline & Midspan of side-span & Deflection[mm] & -7 & -11 \\
\hline
\end{tabular}




\section{Comparison of Intensity and Stiffness}

The moments in midspan of mid-span and side-span under dead load are both hogging moment, which means the girder would show arch phenomenon under the permanent loads; and the upper and lower compressive stress is less than the allowable compressive stress. Therefore, the composite beam will have a larger bearing capacity compared with concrete beam. The deflection of composite beam in midspan of mid-span and side-span is larger than that of concrete beam, which means that the stiffness of composite beam is smaller and the aseismic capacity is larger. Table 3 shows the result of comparison of intensity and stiffness.

\section{CONCLUSIONS}

In this study, the comparison of material and intensity and stiffness between concrete beam and composite beam with corrugated steel webs was studied.

(1) The composite beam has saving on the material quantity of concrete, steel strand, fining twisted steel and steel bar. Also, the use of composite beam would avoid burdensome procedure and speed the construction period.

(2) Considering the intensity and stiffness, composite beam would have a larger bearing capacity compared with concrete beam, and the stiffness of composite beam is smaller and the aseismic capacity is larger.

\section{ACKNOWLEDGMENT}

The author declares that they have no conflict of interest.

\section{REFERENCES}

[1] Qiang XU, Shui WAN, Design and application of corrugated steel web PC composite box girder bridge, Bei Jing, 2009.

[2] Qian-Dian CAI, Yi-Yuan RAN, Discussion on the structural characteristics of corrugated steel web and the structure of girder, Bridge Construction, 1994, 01:26-30.

[3] Lan LIU, Tie-Wan CUI, The design and construction of this bridge: the prestressed concrete box girder bridge of corrugated steel web with the cantilever erection method, Foreign Bridges, 1999(03):18-25.

[4] Shu-qin LI, Jian-Bing CHENG, Shui WAN, Hua-Li CHENG. Design and construction of several corrugated steel web PC composite box girder Bridges in China, Engineering Mechanics, 2009, S1:115-118. 